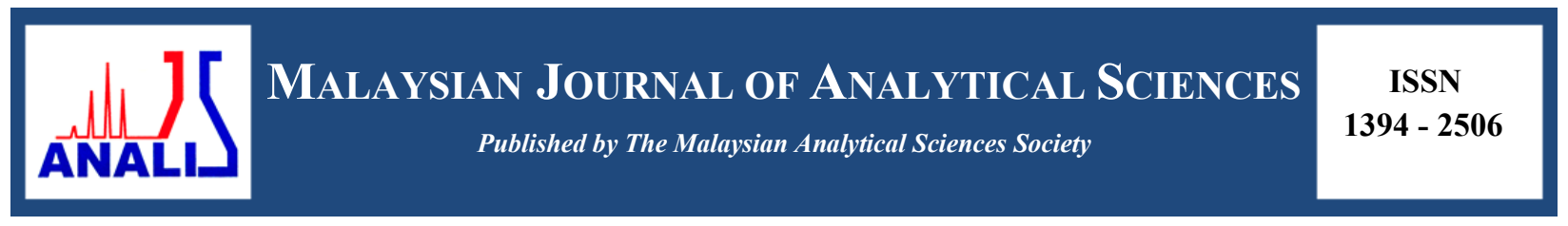

\title{
SCREENING OF TROPICAL NATIVE AQUATIC PLANTS FOR POLISHING PULP AND PAPER MILL FINAL EFFLUENT
}

\author{
(Saringan Tumbuhan Akuatik Tropika Tempatan untuk Rawatan Penyudahan Sisa Pulpa dan \\ Kertas) \\ Jamilah Ahmad ${ }^{1}$, Siti Rozaimah Sheikh Abdullah ${ }^{1 *}$, Hassimi Abu Hassan ${ }^{1}$, Reehan Adne Abdul Rahman ${ }^{1}$, \\ Mushrifah Idris $^{2}$ \\ ${ }^{I}$ Department of Chemical and Process Engineering, Faculty of Engineering and Built Environment \\ ${ }^{2}$ Tasik Chini Research Centre, Faculty of Science and Technology \\ Universiti Kebangsaan Malaysia, 43600 UKM Bangi, Selangor, Malaysia \\ *Corresponding author: rozaimah@ukm.edu.my
}

Received: 21 October 2015; Accepted: 14 June 2016

\begin{abstract}
Pulp and paper mill industry is one of the biggest water users that produce wastewater containing dye and various toxic compounds. The study was conducted to screen for potential tropical native aquatic plants, which can be used in phytoremediation mainly for the removal of colour and chemical oxygen demand (COD) from pulp and paper mill effluent. Three selected tropical native aquatic plants, Scirpus grossus, Azola pinnata and Salvinia molesta were planted in a greenhouse at UKM for screening test. Real final effluent from a pulp and paper mill in Pahang was characterized and contained 181 PtCo for colour and $72.4 \mathrm{mg} / \mathrm{L} \mathrm{COD}$ at $\mathrm{pH}$ 8.1. This wastewater was exposed to weed plant, Scirpus grossus and floating plants, Azola pinnata and Salvinia molesta. The final effluent was analysed after $28^{\text {th }}$ day of exposure. The percentage of colour removal for the three tropical native plants Scirpus grossus, Azola pinnata and Salvinia molesta were 50.28\%, 43.09\% and 49.72\% respectively. While for COD removal, all the three plants successfully removed $100 \%$ COD. From the result, the best tropical native aquatic plant to remove colour and COD for pulp and paper mill effluent is Scirpus grossus.
\end{abstract}

Keywords: biological treatment, phytoremediation, effluent, colour, chemical oxygen demand

\section{Abstrak}

Industri kilang kertas adalah salah satu pengguna air yang terbanyak dan menghasilkan air sisa yang mengandungi pewarna dan pelbagai sebatian toksik. Kajian ini dijalankan untuk menyaring bagi tumbuhan tropika asli yang berpotensi untuk proses fitoremediasi dalam penyingkiran warna dan permintaan oksigen kimia (COD) daripada sisa air kilang pulpa dan kertas. Tiga jenis tumbuhan tropika asli telah dipilih iaitu Scirpus grossus, Azola pinnata dan Salvinia molesta ditanam dalam rumah tumbuhan di UKM untuk ujian saringan. Efluen sebenar dari sebuah kilang pulpa dan kertas di Pahang telah dicirikan dan mengandungi 181 PtCo untuk warna dan $72.4 \mathrm{mg} / \mathrm{L}$ untuk COD pada $\mathrm{pH}$ 8.1. Air sisa ini telah didedahkan kepada tumbuhan rumpai iaitu Scirpus grossus dan tumbuhan terapung Azola pinnata dan Salvinia molesta. Efluen ini dianalisis selepas diuji/didedahkan sehingga hari ke-28. Penyingkiran warna untuk tiga tumbuhan asli yang dipilih iaitu Scirpus grossus, Azola pinnata dan Salvinia molesta adalah masing-masing sebanyak 50.28\%, 43,09\% dan 49,72\%. Manakala bagi penyingkiran COD bagi Scirpus grossus, Azola pinnata dan Salvina Natans ialah $100 \%$ penyingkiran. Daripada keputusan itu, tumbuhan tropika asli yang terbaik untuk menyingkirkan warna dan COD dari effluen kilang pulpa dan kertas adalah Scirpus grossus.

Kata kunci: rawatan biologi, fitoremediasi, efluen, warna, permintaan oksigen kimia 


\section{Introduction}

In Malaysia, there have been more than one billion capacities of pulp and paper. According to Roda and Rathi [1], Malaysia has 67 of pulp and paper mill industries that produce papers from pulp or recycled paper. These industries produce about 76 to $228 \mathrm{~m}^{3}$ of water per tonne. Pulp and paper mill industries are also known as the sixth industry contributing pollution to environment [2-3]. Pollutants released from pulp and paper mill effluent into environment cause numerous problems and physiological impairment. Due to high organic pollutants in the pulp and paper mill effluent will affect aquatic communities [10].

The problems associated with pulp and paper mill effluents are $\mathrm{pH}$, colour, and high levels of Biochemical Oxygen Demand (BOD), Chemical Oxygen Demand (COD), Suspended Solid (SS) and Absorbable Organic Halides (AOX). Paper manufacturing process releases chlorinated substances in the effluent as the major contaminants formed [4-7]. Pulp and paper mill wastewater is a concern for the environment due to its after effects. Some researchers [8-10] more focused on environmental friendly technologies for treatment of wastewater. They use biological approach for the removal of contaminants from the effluent. The biological treatment processes are able to reduce colour, COD, BOD and toxic low molecular weight chlorinated lignin derivatives.

Last few decades, there has been an increase in improving the ability of plants to remove environmental pollutants. Genes from microbes and plants are being used successfully to enhance the ability of plants to tolerate, remove and degrade pollutants [11]. Therefore, phytoremediation on a basis of plant is suitable for biological treatment for pulp and paper mill effluent. Phytoremediation uses plants to treat contaminated effluent. This technology has been extensively reviewed through literature studies [12-19]. Phytoremediation takes advantage of the natural ability of plants to extract chemicals from water, soil and air using energy from sunlight. Some advantages and disadvantages are listed in Table 1. Its primary advantage is that it is approximately 10 times less expensive than conventional strategies [20]. Other advantages of phytoremediation over the engineering or bioremediation methods include the possibility of a useful product such as wood, pulp or bioenergy [21]. Plants act as soil stabilizer, minimizing the amount of contaminated dust that could leave the site and enter the surrounding neighbourhoods [11].

Table 1. Advantages and disadvantages of phytoremediation

\begin{tabular}{ll}
\hline Advantages & Disadvantages \\
\hline Less costly than mechanical methods & Limited to shallow contaminants \\
Passive, solar driven & Phytotoxicity of contaminants \\
High public acceptance & Slower than mechanical methods \\
Retains topsoil & Unknown effects of biodegradation products \\
Less secondary waste generation & Potential of contaminants to enter the food chain. \\
\hline
\end{tabular}

Phytoremediation in pulp and paper mill effluent treatment may take one of several forms: phytoextraction, rhizofiltration, phytostabilization, and phytovolatilization. Phytoextraction refers to process in which plants are used to concentrate metals from the soil into the roots and shoots the plant; rhizofiltration is the use of plant roots to absorb, concentrate or precipitate contaminants from effluents. Phytostabilization is the uptake and release into atmosphere of volatile materials such as mercury [22].

The aim of this study is to screen for potential tropical native aquatic plants, which can be used in phytoremediation mainly for polishing of colour and COD from pulp and paper mill final effluent.

\section{Plant propagation}

\section{Materials and Methods}

The selected plant, Scirpus grossus were planted in a greenhouse at UKM for preliminary studies and as a stock for further studies in phytotoxicity. The plant sources were taken from Tasik Chini, Pahang. The tenure of Scirpus 
grosuss is between $8-10$ weeks. Upon reaching maturity, this plant was taken for preliminary test. For Azola pinnata and Salvinia molesta, they were grown in greenhouse. Figure 1 (a) shows the samplings of Scirpus grossus taken at Tasik Chini, (b) matured Scirpus grossus planted at greenhouse, (c) Salvinia molesta and (d) Azola pinnata in greenhouse, Universiti Kebangsaan Malaysia.

a)

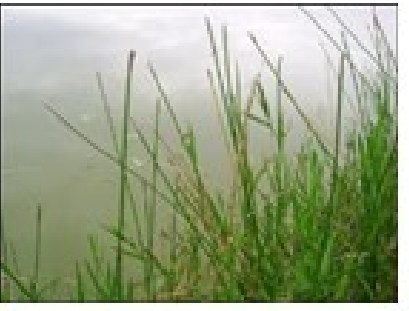

c)

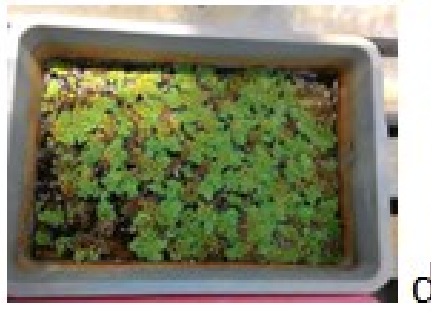

b)
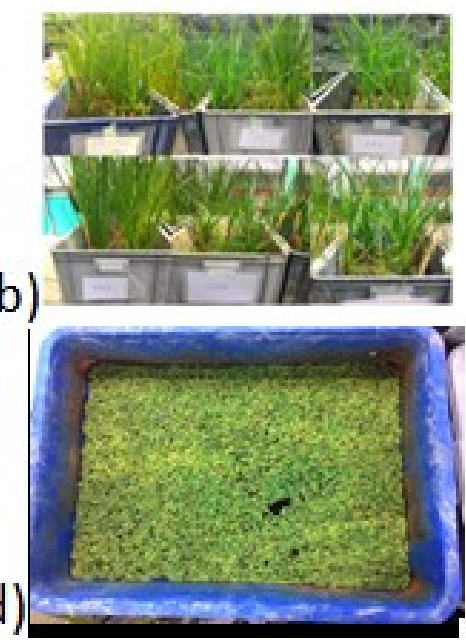

Figure 1. (a) Scirpus grossus at Tasik Chini, (b) matured Scirpus grossus at greenhouse, c) Salvinia molesta, (d) Azola pinnata at greenhouse

\section{Experimental set - up for preliminary test}

The preliminary test was conducted batch wise in crates of $10 \mathrm{~L}$. Real final effluents from a pulp and paper mill industry in Pahang acted as a contaminant. All crates for Scirpus grossus filled with $5 \mathrm{~kg}$ of sands and $2 \mathrm{~L}$ of wastewater except for control contaminant (CC) filled with only tap water. All crates would be topped up with tap water by $1 \mathrm{~L}$ for every 2 days. The schematic diagram for experimented sets of Scirpus grossus is shown in Figure 2. There were four crates containing eight plants in each crate labelled as CC, R1, R2 and R3. The Scirpus grossus planted in two rows.

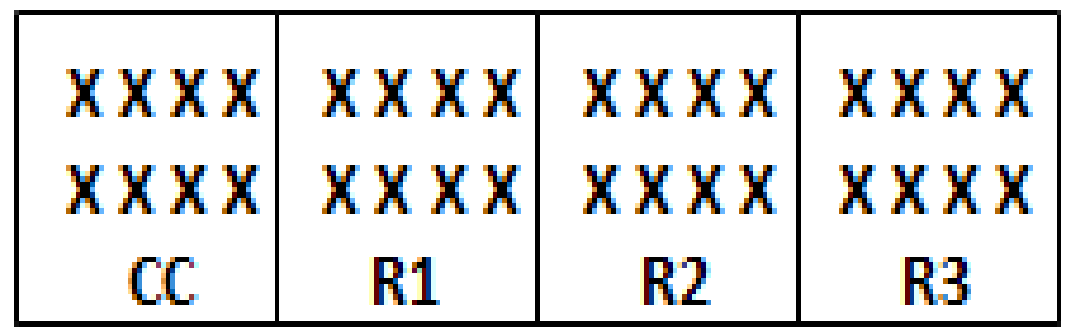

Figure 2. Schematic diagram of sets of Scirpus grossus in preliminary test

Floating plants of Salvinia molesta and Azola pinnata were prepared in three crates for each plant as shown in Figure 3 and Figure 4, respectively. Crate for control contaminant for Salvinia molesta and Azola pinnata labelled as $\mathrm{SC}$ and $\mathrm{AC}$ respectively containing $2 \mathrm{~L}$ of tap water. Crates for sample (S1/A1 \& S2/A2) contained $2 \mathrm{~L}$ of wastewater. The crates were filled with $300 \mathrm{~g}$ of the floating plants. 


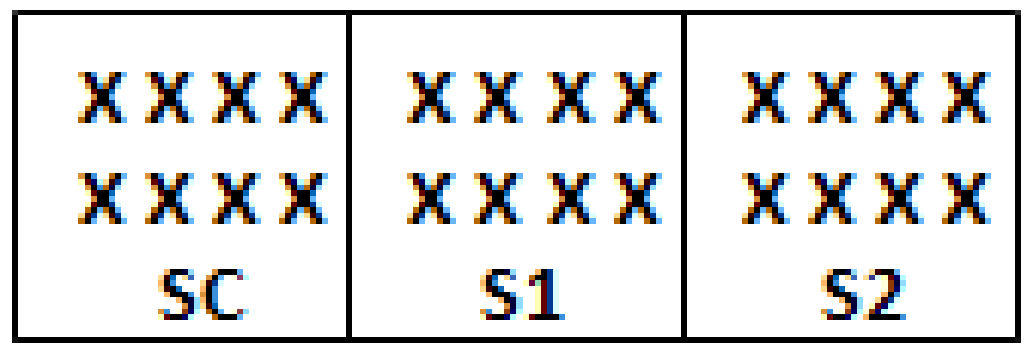

Figure 3. Schematic diagram of sets of Salvinia molesta in preliminary test

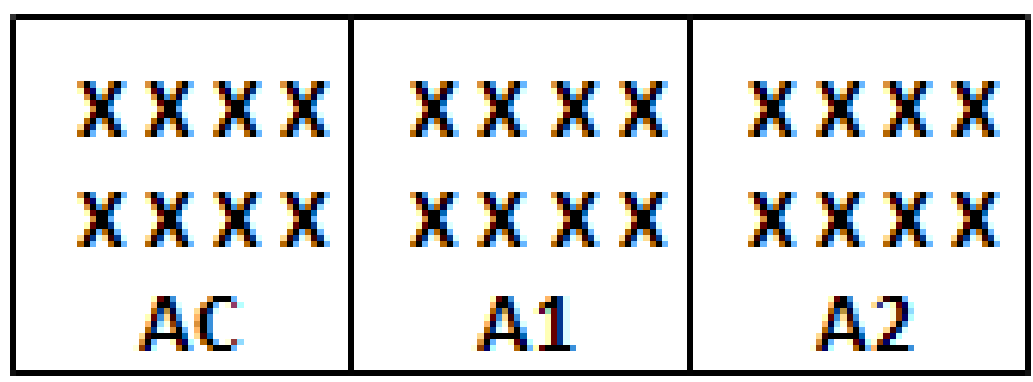

Figure 4. Schematic diagram of sets of Azola pinnata in preliminary test

After $28^{\text {th }}$ day exposure, liquid sample from each crate were collected for determining the colour and COD.

\section{Physical plant growth observation}

\section{Results and Discussion}

The observation on the physical appearance of Scirpus grossus, Salvinia molesta and Azola pinnata during the preliminary test when exposed to real wastewater was summarized in Table 2.

Table 2. Observation and physical appearance of Scirpus grossus, Salvinia molesta and Azola pinnata on day 0 compared to day 28

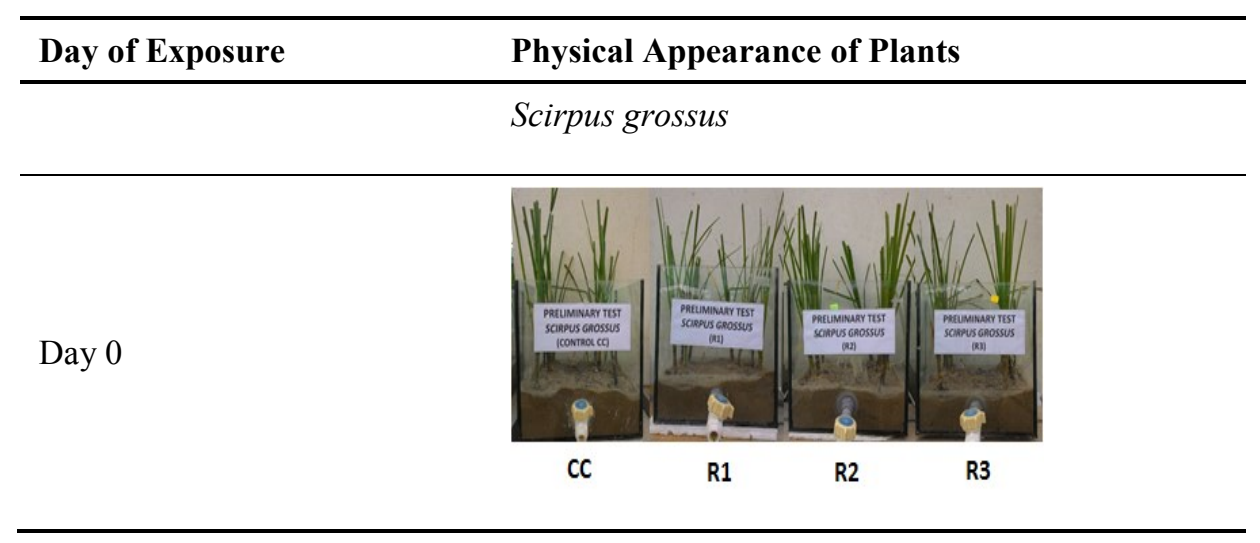


Table 2 (cont'd). Observation and physical appearance of Scirpus grossus, Salvinia molesta and Azola pinnata on day 0 compared to day 28

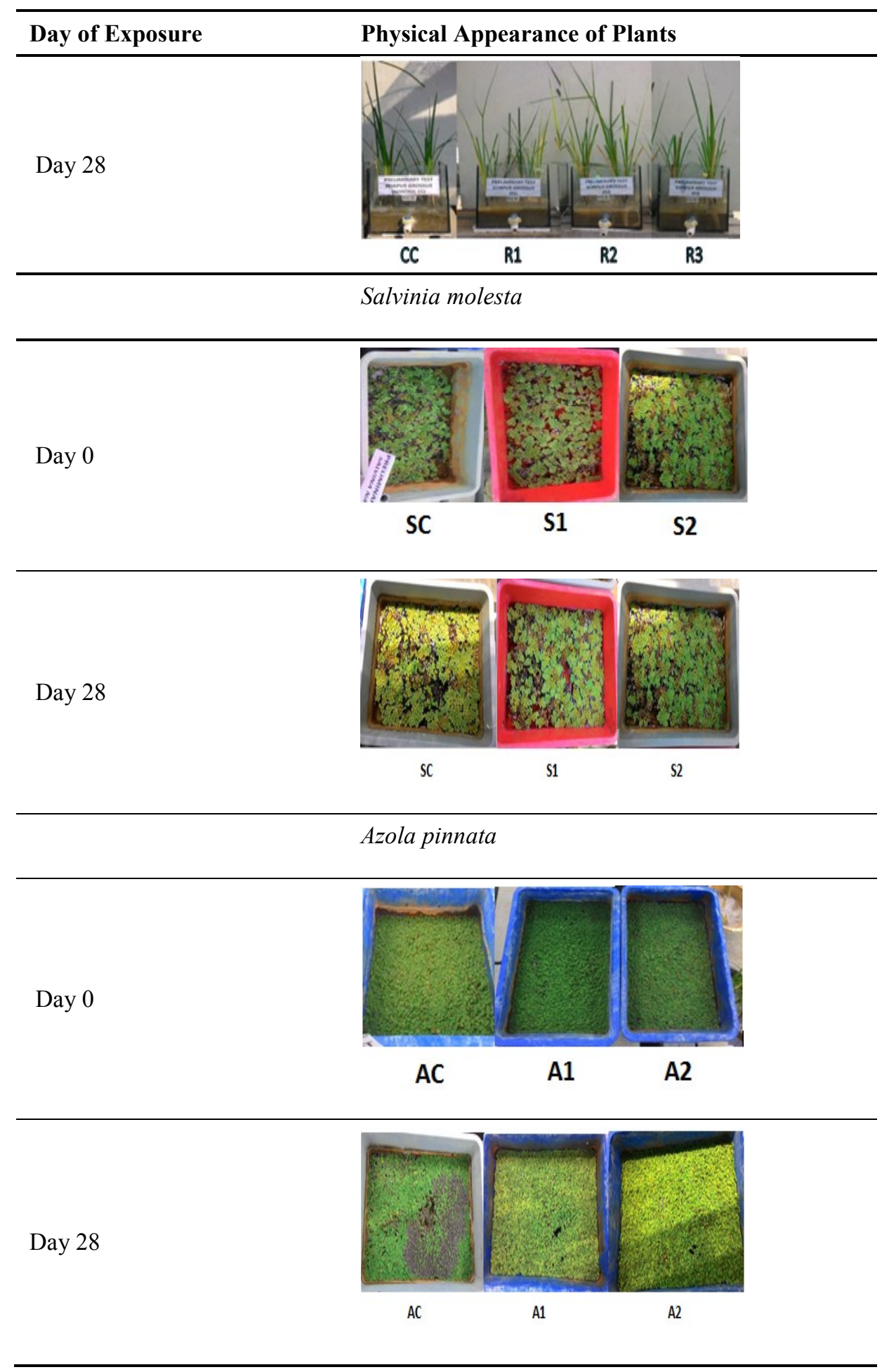


From the observation, the Scirpus grossus still survived until day 28. Nevertheless, there were also withered plants during the preliminary test. For Scirpus grossus, it started withered on day 7 compared to the control contaminant (CC) started on day 10. After day 28; the leaves grew in almost $20 \mathrm{~cm}$ higher than before, showing that after exposure, the Scirpus grossus can still survive and grow. Salvinia molesta and Azola pinnata withered starting on day 14 for both floating plants. The control crate withered faster than the contaminant crate. However, both floating plants can survive until day 28.

\section{Removal of colour and COD}

The characterization results of wastewater before and after exposure for all plants were summarized in Table 3 . From the observation, colour and COD decreased from day 3. From Table 3, COD was totally removed by all plants. In addition, $50.28 \%, 49.72 \%$ and $43.09 \%$ of colour were removed by Scirpus grossus, Salvinia molesta and Azola pinnata respectively.

Table 3. Characterization of wastewater after exposure

\begin{tabular}{llll}
\hline Types of plants/characteristic & Colour (PtCo) & COD (mg/L) \\
\hline Scirpus grossus & Average & 90 & 0 \\
& Percentage (\%) & 50.28 & 100 \\
Salvinia molesta & Average & 91 & 0 \\
& Percentage (\%) & 49.72 & 100 \\
Azola pinnata & Average & 103 & 0 \\
& Percentage (\%) & 43.09 & 100 \\
Wastewater & & 181 & 72.4 \\
\hline
\end{tabular}

Figure 5 shows the percentage removal of colour and COD. Hence, from this study, the most suitable tropical native plant used in colour and COD removal is Scirpus grossus.

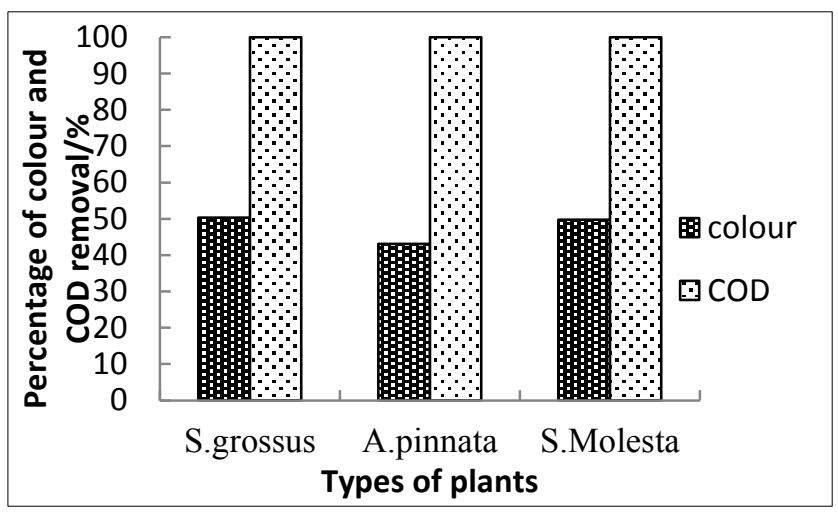

Figure 5. Removal of colour and COD by three plants Scirpus grossus, Salvinia molesta and Azola pinnata 


\section{Conclusion}

The results showed that between the three plants, Scirpus grossus, Salvinia molesta and Azola pinnata are able to remove colour and COD from real pulp and paper mill final effluent. Nevertheless, Scirpus grossus is the best tropical native plant for colour and COD removal through phytoremediation. Hence, Scirpus grossus is recommended for treatment wastewater pulp and paper mill.

\section{Acknowledgement}

The authors would like to thank to Faculty of Engineering and Built Environment and Tasik Chini Research Centre, Universiti Kebangsaan Malaysia (UKM) and Ministry of Higher Education, Malaysia for granting this project under DIP-2014-020.

\section{References}

1. Roda, J. M. and Rathi, S. (2006). Malaysia report: Feeding China's expending demand for wood pulp. Centre For International Forestry Research. Jakarta, Indonesia.

2. Ali, M. and Sreekrishnan, T. R. (2001). Aquatic toxicity from pulp and paper mill effluent: A review. Advances in Environment Research, 5: 175 - 196.

3. Meagher, R. B. and Heaton, A. C. P. (2005). Strategies for the engineered phytoremediation of toxic element pollution: Mercury and arsenic. Journal of Industrial Microbiology and Biotechnology, 32: 502 - 513.

4. Chaudhary S, Rohella R, Manthan M. and Sahoo N (2002). Decolorization of craft paper mill effluent by white rot fungi. Journal of Microbiology, 38: $221-224$.

5. Hossain, M. S. K, Das, M. and Ibrahim, S. H. (2001). Aerobic studies on pollution abatement of sulfite pulp bleaching effluent using Phanerochaete chrysosporium (MTCC-787). Journal of Industrial Pollution Control, 17: 191 - 200.

6. Jayaramraja, P. R, Anthony T, Rajendran R. and Rajkumar K (2001). Decolourisation of paper mill effluent by Aspergillus fumigatus in bioreactor. Pollution Research, 20: $309-312$.

7. Pokhrel D. and Viraraghavan T. (2004) Treatment of pulp and paper mill wastewater - A review. Science of Total Environment, 333: 37 - 58.

8. Barton, D. A, Lee, J. W, Bukley, D. B. and Jett, S. W. (1996). Biotreatment of kraft mill condensate for reuse. Proceeding Tappi Minimum Effluent Mills Symposium, GA Atlanta, USA.

9. Nagarathamma R, Bajpai P, Bajpai PK (1999) studies on decolourisation, decolourisation, degradation and detoxification of chlorinated lignin compunds in kraft bleaching effluents by Ceriporiopsis subvermispora. Process Biochemistry, 34: 939 - 948.

10. Purnima, D. and Kumar, V. (2014). Biological approach for the treatment of pulp and paper effluent in sequence batch reactor. Journal of Bioremediation \& Biodegradation, 5 (3): 1 - 10.

11. Doty, S. L. (2008). Enhancing phytoremediation through the use of transgenics and endophytes. New Phytologist, 179: $318-333$.

12. Schnoor, J. L, Licht, L. A, McCutcheon, S. C., Wolfe, N. L. and Carreira, L. H. (1995). Phytoremediation of contaminated soils and sediments. Environmental Science and Technology, 29: 318 - 323.

13. Salt, D.E., Smith, R. D., Raskin, I. (1998). Phytoremediation. Annual Review of Plant Physiology and Plant Molecular Biology, 49: 643 - 668 .

14. Meagher, R. B. (2000). Phytoremediation of toxic elemental and organic pollutants. Current Opinion in Plant Biology, 3: $153-162$.

15. Dietz, A. and Schnoor, J. L. (2001). Advance in phytoremediation. Environmental Health Perspectives, 109: $163-168$.

16. McCutcheon, S. C. and Schnoor, J. L. (2003). Phytoremediation: transformation and control of contaminants. New Jersey, NJ, USA: John Wiley \& Sons, Inc.

17. Newman, L.A. and Reynolds, C. M. (2004). Phytodegradation of organic compounds. Current Opinion in Biotechnology,15: $225-230$.

18. Suresh, B. and Ravishankar, G. A. (2004). Phytoremediation - A novel and promising approach for environmental clean - up. Critical Reviews in Biotechnology, 24: 97 - 12.

19. Pilon-Smith, E. A. H. and Freeman, J. L. (2006). Environmental cleanup using plants: Biotechnological advances and ecological consideration. Frontiers in Ecology and The Environment, 4: 203 - 210. 
Jamilah et al: SCREENING OF TROPICAL NATIVE AQUATIC PLANTS FOR POLISHING PULP AND PAPER MILL FINAL EFFLUENT

20. Chappel, J. (1998). Phytoremediation of TCE in groundwater using populus. US Environmental Protection Agency.

21. Stanton, B, Eaton J, Johnson J, Rice D, Schuette B, Moser B. 2002. Hybrid popular in the pacific Northwest. Journal of Forestry, 100: 28 - 33.

22. Yan-de, J., Zhen-li, H. E. and Xiao-e, Y. (2007). Role of soil rhizobacteria in phytoremediation of heavy metal contaminated soils. Journal of Zhejiang University Science B, 8(3):192 - 207. 